\title{
NUTRITIONAL STATUS AND DIETARY INTAKE IN NON-CIRRHOTIC ADULT CHRONIC HEPATITIS C PATIENTS
}

\author{
Catarina B A GOTTSCHALL 1,2 , Thainá G PEREIRA ${ }^{3}$, Estela I RABITO ${ }^{4}$ and \\ Mário R ÁLVARES-DA-SILVA ${ }^{2,5}$
}

Received 24/3/2015 Accepted 15/5/2015

\begin{abstract}
Background - The hepatitis C virus is one of the main causes of liver disease worldwide and may develop nutritional deficiencies. Objective - The objective of this study was to assess and compare different nutritional status methods of adult patients with chronic hepatitis $\mathrm{C}$ virus, and to describe inadequacies in dietary intake. Methods - A cross-sectional study was conducted with adult outpatients with hepatitis $\mathrm{C}$ virus at a Brazilian hospital. Nutritional assessment included the 24-hour dietary recall, anthropometry (body weight, height, body mass index, triceps skinfold, mid-upper arm circumference, mid-arm muscle circumference, mid-upper arm muscle area, adductor policis muscle), Subjective Global Assessment, Royal Free Hospital Global Assessment and handgrip strength. Results - A total of 94 outpatients (ages 30 to 76 years), was included, 46 were men. The prevalence of malnutrition as measured by the different methods was $6.4 \%$ (body mass index); 60.6\% (handgrip strength), and 53.2\% (Royal Free Hospital Global Assessment). There was correlation between mid-upper arm circumference and mid-arm muscle circumference $(\mathrm{r}=0.821)$, mid-upper arm circumference and triceps skinfold $(\mathrm{r}=0.575)$ and mid-upper arm circumference and mid-upper arm muscle area $(\mathrm{r}=0.781)$. Energy and protein intakes were below recommended levels in $49(52.1 \%)$ and $44(46.8 \%)$ of patients, respectively. Inadequate calcium, potassium, zinc and vitamin $\mathrm{C}$ intakes occurred in $92.6 \%, 97.9 \%, 63.8 \%$ and $60.6 \%$ of patients. There was an association between dietary energy and protein intake with Royal Free Hospital Global Assessment $(P<0.001)$ and a tendency for them to be associated with handgrip strength $(P=0.076$ and $P=0.054)$. Conclusion - Malnutrition is frequently in hepatitis $\mathrm{C}$ virus patients. They have high prevalence of inadequate energy, protein and micronutrients intake, even in the absence of cirrhosis.
\end{abstract}

HEADINGS - Nutrition Assessment. Chronic hepatitis C. Anthropometry. Protein-energy malnutrition.

\section{INTRODUCTION}

The hepatitis $\mathrm{C}$ virus (HCV) is one of the main causes of chronic liver disease ${ }^{(30)}$ and it is estimated that $3 \%$ of the world population is currently infected ${ }^{(3,32)}$. In Brazil, the estimated prevalence in the general population is between 1 to $2 \%{ }^{(31)}$.

Liver disease, affects nutrient digestion, absorption, storage and metabolism, which may lead to vitamin and mineral deficiencies and protein-energy malnutrition $^{(6)}$.

Malnutrition is frequently in this population, but it is undiagnosed ${ }^{(26)}$. It is directly related with patient prognosis, and leads to increased morbidity, mortality and hospital expenditures in patients with cirrho$\operatorname{sis}^{(2,10,20)}$. There is no gold standard to the diagnosis of malnutrition in liver disease patients ${ }^{(2,12,13)}$.
As there are few studies on the nutritional status of non-cirrhotic HCV patients ${ }^{(12,20)}$, the objectives of this study were to assess the nutritional status of this population, comparing different nutritional assessment methods, and to evaluate their dietary intake.

\section{METHODS}

A cross-sectional study was performed with non-cirrhotic chronic HCV patients (18 years or older), of both gender, attending the outpatient clinic at the Gastroenterology Division (Liver Unit) of the Hospital de Clínicas de Porto Alegre (HCPA), Brazil. Patients with biopsy-proven or clinical evident cirrhosis, hepatocellular carcinoma, chronic renal failure, HIV and/ or hepatitis B virus co-infection and those unable to be tested with the dynamometer were excluded.

Declared conflict of interest of all authors: none

Disclosure of funding: no funding received

Research performed at: Departamento de Gastroenterologia, Unidade de Hepatologia, Hospital de Clínicas de Porto Alegre, Porto Alegre, RS, Brasil.

${ }^{1}$ Departamento de Nutrição, Universidade Federal de Ciências da Saúde de Porto Alegre, RS; ${ }^{2}$ Programa de Pós-Graduação Ciências em Gastroenterologia, Universidade Federal do Rio Grande do Sul, RS: ${ }^{3}$ Departamento de Nutrição, Universidade Federal do Paraná, PR; ${ }^{4}$ Faculdade de Nutrição, Universidade Federal de Ciências da Saúde de Porto Alegre, RS; ${ }^{5}$ Faculdade de Medicina, Universidade Federal do Rio Grande do Sul, Departamento de Gastroenterologia, Unidade de Hepatologia, Porto Alegre, RS. Brasil.

Porto Alegre, RS. Brasil. 245 - CEP: 90050-170 - Porto Alegre, RS, Brasil. E-mail catarina@ufcspa.edu.br 
Data collection occurred between April and September of 2012. All included patients signed an informed consent form. The study was approved by the HCPA's Ethics in Research Board.

Information on $\mathrm{HCV}$ genotype, liver biopsy, and antiviral therapy was obtained. Current body weight, height, body mass index (BMI), triceps skinfold (TSF) and mid-upper arm circumference (MUAC) were taken. Mid-arm muscle circumference (MAMC) and mid-upper arm muscle area (MUAMA) were then calculated ${ }^{(14)}$. The anthropometric parameters were classified based on Frisancho ${ }^{(11)}$, according to the sex and age. Patients were asked about their usual body weight and based on the reported values, their 6-month weight loss was calculated. Finally, the adductor policis muscle (APM) ${ }^{21}$ was measured and classified according to Lameu (2004). Handgrip strength (HGS) in the non-dominant hand ${ }^{(28)}$ was classified according to Schlüssel (2008). Subjective Global Assessment (SGA), proposed by Detsky et al. ${ }^{(8)}$, which is based on patients' clinical history and physical examination, and Global Assessment proposed by the Royal Free Hospital $(\mathrm{RFH}-\mathrm{GA})^{(22)}$ were also assessed. The 24-hour recall ${ }^{(9)}$ (24 $\mathrm{hR}$ ) was used to assess dietary intake. Energy and protein intake were compared to ESPEN's ${ }^{(25)}$ recommendations for patients with liver disease, which are 25 to $30 \mathrm{kcal} / \mathrm{kg}$ and 1.0 to $1.2 \mathrm{~g} / \mathrm{kg}$ of current body weight, respectively. Micronutrient intake was compared to the DRIs ${ }^{(15-19)}$.

\section{Statistical analysis}

The database for this study was created using Microsoft Office Excel 2007, and the Statistical Package for Social Science (SPSS, version 18.0.0) software was used for the data analysis. Categorical variables were described using frequency tables and continuous variables had their means and standard deviations calculated. Pearson's chi-squared test was used for the comparative analysis between categorical variables. Pearson's correlation and Bland-Altman's analysis, respectively, were used to assess the correlation and agreement between the different nutritional status assessment methods. The kappa coefficient was also used to verify the agreement between the different methods.

\section{RESULTS}

Ninety-four patients were included, and their characteristics are shown in Table 1. Their average age was 52.6 years ( 30 to 76 years), and 23 were 60 years old or older. Eight $(8.5 \%)$ patients had not undergone liver biopsy, but had no signs of clinically evident cirrhosis.

Average anthropometric figures are shown in Table 2. Two patients had significant 6 -month weight loss (ranging between $5 \%$ to $10 \%$ ) and four $(4.2 \%)$ patients had severe weight loss of more than $10 \%$ of their usual weight. The percentage of individuals classified as having malnutrition according to each method is described in Figure 1. During the physical exam which is part of the SGA, no patients had edema or ascites.

When compared by the kappa coefficient, only the MUAC
TABLE 1. Characteristics of hepatitis $C$ virus outpatients

\begin{tabular}{lcc}
\hline & Man $\mathrm{n}=46$ & Woman $\mathrm{n}=48$ \\
\hline $\begin{array}{l}\text { Age (years) } \\
\text { Mean }\end{array}$ & 51.8 & 53.3 \\
Treatment & & \\
Yes & 13 & 13 \\
No & 33 & 35 \\
METAVIR & & \\
F0 & 2 & 13 \\
F1 & 18 & 10 \\
F2 & 16 & 16 \\
F3 & 6 & 5 \\
Without diagnosis & 4 & 4 \\
\hline
\end{tabular}

TABLE 2. Anthropometric, adductor policis muscle and handgrip strength values in hepatitis $C$ virus outpatients

\begin{tabular}{lcc}
\hline & Mean $(\mathrm{SD})$ & \% \\
\hline Height $(\mathrm{cm})$ & 163 & 8.0 \\
Body weight $(\mathrm{kg})$ & 70.2 & 12.4 \\
BMI $\left(\mathrm{kg} / \mathrm{m}^{2}\right)$ & 26.3 & 4.1 \\
MUAC $(\mathrm{cm})$ & 101.3 & 13.0 \\
TSF $(\mathrm{mm})$ & 102.4 & 45.4 \\
MAMC $(\mathrm{cm})$ & 104.3 & 12.2 \\
MUAMA $\left(\mathrm{cm}^{2}\right)$ & 108.2 & 33.3 \\
HGS $(\mathrm{kg} / \mathrm{f})$ & 74.6 & 31.7 \\
APM $(\mathrm{mm})$ & 16.6 & 3.5 \\
\hline
\end{tabular}

BMI: body mass index; MUAC: mid-upper arm circumference; TSF: triceps skinfold; MAMC: mid-arm muscle circumference; MUAMA: mid-upper arm muscle área; HGS: handgrip strenght; APM:adductor policis muscle.

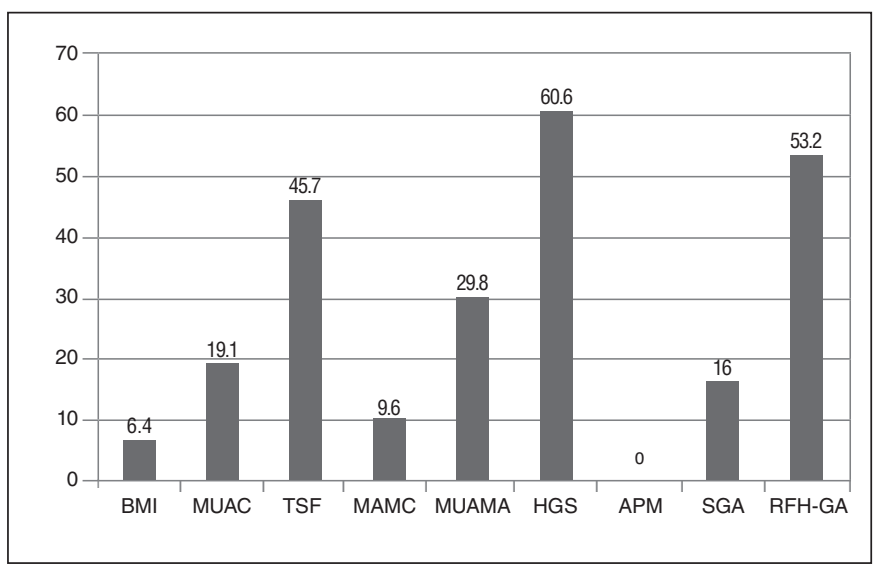

FIGURE 1. Malnutrition according to different nutritional assessment methods.

BMI: body mass index; MUAC: mid-upper arm circumference; TSF: triceps skinfold; MAMC: mid-arm muscle circumference; MUAMA: mid-upper arm muscle área; HGS: handgrip strenght; APM: adductor policis muscle; SGA: subjective global assessment; RFH-GA: Royal Free Hospital Global Assessment. 
$(\mathrm{k}=0.448)$ agreed moderately with the MUAMA $(\mathrm{k}=0.490)$. According to the Bland-Altman analysis, however, there was correlation between MUAC and TSF, TSF and MAMC, and TSF and MUAMA. Pearson's linear correlation was shown to be good between MUAC and MAMC $(\mathrm{r}=0.821)$, MUAC and TSF $(r=0.575)$ and MUAC and MUAMA $(r=0.781)$.

Most patients had lower intakes of calcium, potassium, zinc and vitamin $\mathrm{C}$, and higher intakes of sodium, iron, phosphorus and cholesterol (Table 3). Median energy and protein intakes were $24.6 \mathrm{kcal} / \mathrm{kg}$ and $1.16 \mathrm{~g} / \mathrm{kg}$ of current

TABLE 3. Dietary intake of energy, protein and micronutrients and inadequate intake

\begin{tabular}{|c|c|c|}
\hline & Median & Inadequate intake $\mathrm{n}(\%)$ \\
\hline Energy (Kcal/kg AW) & 24.6 & $49(52.1)^{c}$ \\
\hline Protein $(\mathrm{g} / \mathrm{kg} \mathrm{AW})^{\mathrm{a}}$ & $1.16(0.56)$ & $44(46.8)^{c}$ \\
\hline Calcium (mg) & 500.5 & $87(92.6)^{c}$ \\
\hline Iron $(\mathrm{mg})$ & 10.8 & $27(28.7)^{c}$ \\
\hline Sodium (mg) & 1843.2 & $50(53.2)^{\mathrm{b}}$ \\
\hline Phosphorus (mg) & 709.9 & $46(48.9)^{c}$ \\
\hline Potassium (mg) & 1575.1 & $92(97.9)^{c}$ \\
\hline Zinc (mg) & 7.9 & $60(63.8)^{c}$ \\
\hline Vitamin C (mg) & 59.9 & $57(60.6)^{c}$ \\
\hline Cholesterol (mg) & 192.2 & $44(46.8)^{c}$ \\
\hline
\end{tabular}

AW: Actual weight; ${ }^{a}$ mean (SD); ${ }^{\mathrm{b}}$ excessive intake; ${ }^{\mathrm{c}}$ insufficient intake. body weight, respectively. Figure 2 shows the percentage of patients with adequate versus inadequate energy and protein intakes, according to ESPEN ${ }^{(25)}$.

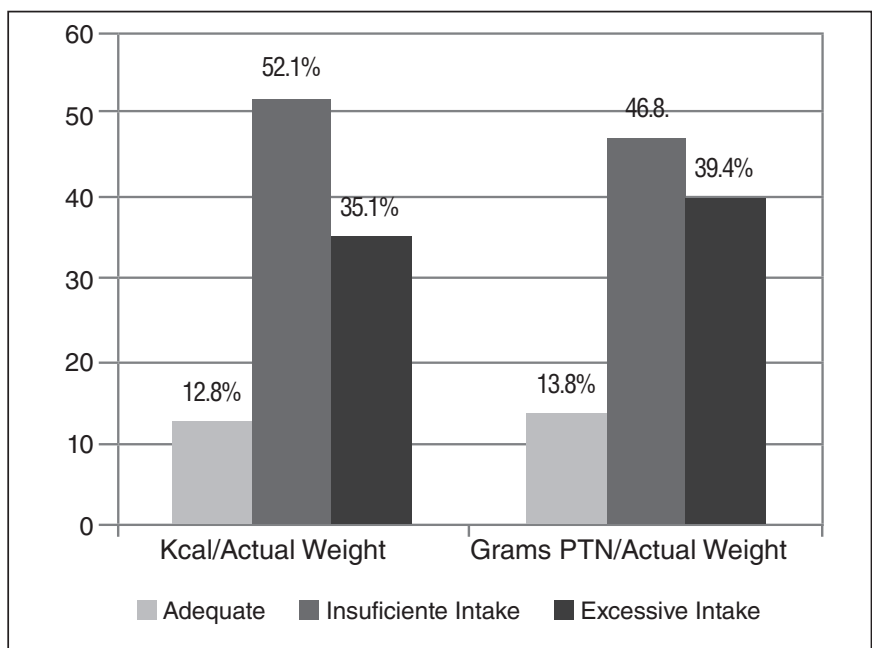

FIGURE 2. Energy and protein intake in hepatitis $C$ virus outpatients

There was a significant association between Royal Free Hospital's Global Assessment and energy and protein intakes $(P<0.001)$, and HGS tended to be associated with dietary intake (energy and protein) $(P=0.054)$. Other correlations between dietary intake and antiretroviral treatment, degree of fibrosis and percent weight loss were not significant (Table 4).

TABLE 4. Association between energy and protein intake and nutritional assessment methods

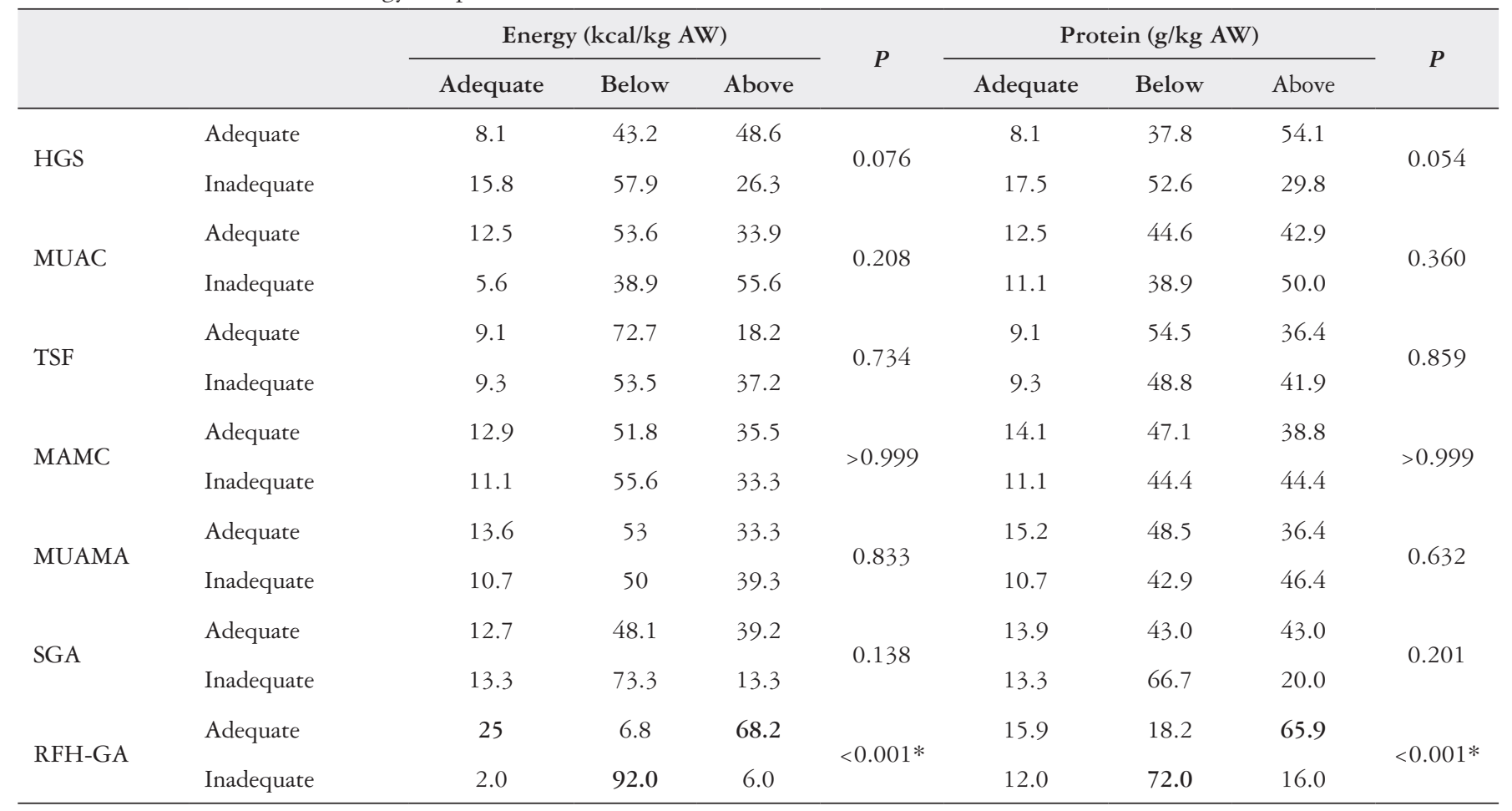

Test $x^{2} . * P<0.005$ (statistically significant). HGS: Handgrip strenght; MUAC: Mid-upper arm circumference; TSF: Triceps skinfold; MAMC: Mid-arm muscle circumference; MUAMA: Mid-upper arm muscle área; SGA: Subjective Global Assessment; RFH-GA: Royal Free Hospital Global Assessment; AW: Actual weight. 


\section{DISCUSSION}

Malnutrition is frequently in patients with liver disease, but in clinical practice little attention is given to this condition. Studies using different methods of nutritional assessment report the prevalence of malnutrition and inadequate energy and protein intakes in patients with cirrhosis who are waiting for a liver transplant ${ }^{(1,2,5,7,10,13,24,27)}$ but few studies assess patients with chronic hepatitis $\mathrm{C}$ without complications, such as cirrhosis ${ }^{(12,20)}$.

In this study, the nutritional assessment methods that were correlation were MUAC and TSF, TSF and MAMC, and TSF and MUAMA. This finding is not clinically relevant, however, given that the amplitude of these measurements is very high, thus demonstrating ample variation between the results of each method.

The results of patients' nutritional status based on their BMI reflect the current nutritional status of the Brazilian population. An increase in the prevalence of overweight has been observed as a consequence of unfavorable changes in the dietary and physical activity patterns of the population (an increase in the consumption of processed foods and a reduction in occupational energy expenditure $)^{(29)}$.

According to the HGS and the RFH-GA indicators, however, more than half of our study population was at risk for malnutrition $-60.6 \%$ and $53.2 \%$, respectively. Ismail et al. ${ }^{(20)}$ studied patients with hepatitis $\mathrm{C}$ of all disease stages (control group, chronic hepatitis C, well-compensated cirrhosis and decompensated cirrhosis), and found a significant risk of malnutrition in the chronic hepatitis C group (14\%), similar to what we found in this study $(16 \%)$. The results of Ismail et al. ${ }^{(20)}$ were unexpected, since the nutritional status of patients with chronic infection without liver complications is expected to closely match that of the control group. Our study, however, is limited in not having a control group for further statistical comparisons.

However, the high prevalence of patients at risk for malnutrition according to the RFH-GA is justified by the also high percentage of patients with inadequate energy intake, as assessed by the 24-hour recall (52.1\%). The RFH-GA takes dietary intake as well as BMI and MUAC into account, and therefore a statistically significant association was found between this method and energy and protein intakes.

HGS has been shown to be a good alternative in assessing protein depletion by being a superior indicator in detecting cirrhotic patients with malnutrition ${ }^{(2,5,13)}$. Álvares-da-Silva et al. ${ }^{(1)}$ found $100 \%$ of malnutrition in pre-liver transplant patients. Gottschall et al. ${ }^{(13)}$ reported that $79.4 \%$ of patients with cirrhosis had malnutrition according to HGS, and had inadequate energy and protein intakes, which can affect HGS values. In other clinical conditions, such as Chron's disease, as assessed by Bin et al. ${ }^{(4)}$, HGS was found to be more sensitive in detecting malnutrition, thus indicating that it can identify changes affecting patients' nutritional status at an early stage. Peng et al. ${ }^{(24)}$ reported that protein depletion, as measured by neutron activation analysis, affects HGS significantly. In the present study, HGS tended to be associated with both energy and protein intakes. This association, however, needs to be tested in a larger patient sample.

Energy and protein intakes were adequate in 52.1\% and $46.8 \%$ of our sample, respectively, when compared to recommendations for liver disease ${ }^{(25)}$. Roongpisuthipong et al. ${ }^{(27)}$ assessed patients with cirrhosis and also reported lower that recommended energy and protein intakes, as well as similar findings for malnutrition based on TSF and BMI values. Ferreira et al. ${ }^{(10)}$ found that $90.7 \%$ and $75.7 \%$ of patients awaiting a liver transplant had inadequate energy and low protein intakes, respectively. Given that these patients have more advanced liver disease, the prevalence of malnutrition and inadequate dietary intake are expected to be higher.

Insufficient intakes of calcium, potassium, zinc and vitamin C were similar to those reported by Gottschall et al. ${ }^{(13)}$, which were commonly due to unnecessary dietary restrictions and to the low palatability caused by low zinc and restricted salt intakes in these patients' diets ${ }^{(13)}$.

These findings related to inadequacies in dietary intake become significant given the changes in taste and appetite produced by medications for the treatment of hepatitis $C^{(23)}$. Some of these, such as protease inhibitors, must even be administered after meals three times a day, in order to ensure its absorption and adequate serum levels ${ }^{(23)}$. In this study, however, there was no significant association between energy and protein intake and antiviral treatment use.

The low energy and protein intakes found in the present study may explain the prevalence of malnutrition detected by the different methods of nutritional assessment. Although this study did not investigate the cause of reductions in dietary intake, one hypothesis is that it may be due to recommendations by health professionals for patients to restrict certain foods ${ }^{(10,20)}$ or even dietary taboos associated with liver diseases. Ismail et al. ${ }^{(20)}$ reported that most patients restricted protein and fat in their diet, not because of their own or their family's beliefs, but because of professional advice. This could be the reason for the $14 \%$ prevalence of moderate malnutrition in patients with chronic hepatitis $\mathrm{C}$ found in their study. This study, similarly to Ferreira et al. ${ }^{(10)}$, reported that patients are poorly advised to restrict certain foods, especially protein sources, which are still commonly considered as foods to avoid. The authors ${ }^{(20)}$ conclude that, just as liver disease progresses from chronic hepatitis $\mathrm{C}$ to uncompensated cirrhosis, patients' nutritional status similarly evolves from "A" (well-nourished") to "C" (severe malnutrition).

It is worth highlighting that the 24-hour recall method, which was used in this study to assess patients' dietary intake, has the limitation of having been applied only once. Thus, patients' dietary intake assessment may have occurred on an atypical day, which does not reflect their usual daily intake.

The fact that patients assessed in this study who have not yet developed complications associated with the hepatitis $\mathrm{C}$ virus are already at risk of malnutrition and inadequate dietary intake is of particular concern, since it is well recognized that nutrient deficiencies have a direct impact on the clinical 
history of patients with liver disease $\mathrm{f}^{(7,10,13,20,27)}$. This shows the importance of diagnosing and treating malnutrition caused by chronic liver disease before the onset of complications such as cirrhosis and hepatocellular carcinoma.

Malnutrition was prevalent among chronic hepatitis $\mathrm{C}$ patients assessed in this study, but there was no agreement among the different methods of nutritional status assessment. Insufficient energy and protein intakes were highly prevalent, demonstrating that these patients are at risk for malnutrition even before they develop the complications of liver disease such as cirrhosis.

Assessing their nutritional status and dietary intake patterns may substantiate nutrition education strategies as preventive measures in the development of malnutrition in patients with liver disease.

\section{Authors' contributions}

Gottschall CBA has designed the study, data collection, survey execution, analyzed and interpreted the data, writing of text and reviewed it critically for the intellectual quality of the study. Pereira TG has designed the study, data collection, survey execution, analyzed and interpreted the data, writing of text. Rabito EI has interpreted the data and reviewed the text. Álvares-da-Silva MR has designed the study, interpreted the data and reviewed it critically for the intellectual quality of the study.

Gottschall CBA, Pereira TG, Rabito EI, Álvares-da-Silva MR. Estado nutricional e ingestão dietética de adultos portadores de hepatite C crônica. Arq Gastroenterol. 2015,52(3):204-9.

RESUMO - Contexto - O vírus da hepatite C é uma das principais causas de hepatopatia no mundo todo. Hepatopatas podem apresentar deficiências nutricionais e desnutrição, influenciando no seu prognóstico. Objetivo - O objetivo do estudo foi avaliar o estado nutricional de pacientes adultos portadores crônicos do vírus da hepatite $\mathrm{C}$, comparar os métodos de avaliação nutricional e descrever a prevalência de inadequação de ingestão alimentar. Métodos - Foi realizado um estudo transversal em adultos portadores do vírus da hepatite $\mathrm{C}$ não cirróticos e não transplantados em acompanhamento ambulatorial no Hospital de Clínicas de Porto Alegre. A avaliação nutricional incluiu antropometria (peso, altura, índice de massa corporal, prega cutânea tricipital, circunferência do braço, circunferência muscular do braço, área muscular do braço e músculo adutor do polegar), Avaliação Subjetiva Global, Avaliação Subjetiva do Royal Free Hospital, dinamometria e Inquérito Recordatório de 24 horas. Resultados - De 94 pacientes (idade: 30 a 76 anos), 46 eram homens. A prevalência de desnutrição foi de 6,4\% (índice de massa corporal), 60,6\% (dinamometria) e 53,2\% (Avaliação Subjetiva do Royal Free Hospital). Houve correlação entre circunferência do braço e circunferência muscular do braço (r=0,821), circunferência do braço e prega cutânea tricipital $(\mathrm{r}=0,575)$, circunferência do braço e área muscular do braço $(\mathrm{r}=0,781)$. Ingestão energética abaixo do recomendado ocorreu em 49 (52,1\%) indivíduos e baixa ingestão proteica em 44 (46,8\%). Consumo inadequado de cálcio, potássio, zinco, vitamina C ocorreu em 92,6\%, 97,9\%, 63,8\% e 60,6\% da amostra, respectivamente e consumo excessivo de sódio ocorreu em 53,2\%. Houve associação significativa entre o consumo de energia e proteína com o Avaliação Subjetiva do Royal Free Hospital $(P<0,001)$ e uma tendência de associação com a dinamometria $(P=0,076$ e $P=0,054)$. Conclusão - Desnutrição é frequente em portadores crônicos de hepatite C. Pacientes com vírus da hepatite $\mathrm{C}$ têm alta prevalência de ingestão energética e proteica inadequada.

DESCRITORES - Avaliação nutricional. Hepatite C crônica. Antropometria. Desnutrição proteico-calórica. 


\section{REFERENCES}

1. Álvares-da-Silva MR, Gottschall CBA, Waechter FL, Hadlich E, Sampaio JA, Francesconi CFM. The use of early enteral feeding post orthotopic liver transplantation in adults. Arq Gastroenterol. 2004;41(3):147-9.

2. Álvares-da-Silva MR, Reverbel da Silveira T. Comparison between handgrip strength, subjective global assessment, and prognostic nutritional index in assessing malnutrition and predicting clinical outcome in cirrhotic outpatients. Nutrition. 2005;21(2):113-7.

3. Associação Médica Brasileira e Conselho Federal de Medicina. Hepatite C crônica: tratamento. Projeto Diretrizes, 2009.

4. Bin CM, Flores C, Álvares-da-Silva MR, Francesconi CFM. Comparison between handgrip strength, subjective global assessment, anthropometry, and biochemical markers in assessing nutritional status of patients with crohn's disease in clinical remission. Dig Dis Sci. 2010;55:137-44.

5. Bragança ACC, Álvares-da-Silva MR. Prevalence of diabetes mellitus and impaired glucose tolerance in patients with decompensated cirrhosis being evaluated for liver transplantation: the utility of oral glucose tolerance test. Arq Gastroenterol. 2010;47(1):22-7.

6. Canadian guidelines for Health Care Providers. Hepatitis C: Nutrition Care. Dietitians of Canada, 2003.

7. Carvalho L, Parise ER. Evaluation of nutritional status of nonhospitalized patients with liver cirrhosis. Arq Gastroenterol. 2006;43(4):269-74.

8. Detsky AS, McLaughlin JR, Baker JP, Johnston N, Whittaker S, Mendelson RA, Jeejeebhoy KN. What is Subject Global Assessment of Nutritional Status? JPEN 1987;11:8-13.

9. Duarte ACG. Avaliação nutricional: aspectos clínicos e laboratoriais. São Paulo: Atheneu, 2007.

10. Ferreira LG, Anastácio LR, Lima AS, Correia MITD. Desnutrição e inadequação alimentar de pacientes aguardando transplante hepático. Rev Assoc Med Brás. 2009;55(4):389-93.

11. Frisancho AR. Anthropometric standards for the assessment of growth and nutrition status. The University of Michigan Press: Ann Arbor, 1990.

12. Gottschall CBA, Nunes FF, Aydos MED, Bragança AC, Felix DR, Rabito EI, Álvares-da-Silva MR. Contribution of dynamometry and the royal free hospital global assessment to the nutritional assessment of patients with chronic liver diseases. Rev Chil Nutr. 2012;39(4):152-8.

13. Gottschall, CBA, Álvares-da-Silva MR, Camargo ACR, Burtett RM, Silveira TR Nutritional assessment in patients with cirrhosis: the use of indirect calorimetry. Arq Gastroenterol. 2004;41(4):220-4.

14. Heyward VH, Stolarczyk LM. Avaliação da composição corporal aplicada. Barueri: Manole, 2000.

15. Institute of Medicine (IOM). Dietary reference intakes for calcium, phosphorus, magnesium, vitamin D, and fluoride. Washington, D.C.: National Academy Press, 1997a, 454p.
16. Institute of Medicine (IOM). Dietary reference intakes for energy, carbohydrate, fiber, fat, fatty acids, cholesterol, protein, and amino acids. Washington, D.C.: National Academy Press, 2005a, 1357p.

17. Institute of Medicine (IOM). Dietary reference intakes for vitamin A, vitamin K, arsenic, boron, chromium, copper, iodine, iron, manganese, molybdenum, nickel, silicon, vanadium and zinc. Washington, D.C.: National Academy Press, 2001a, $773 \mathrm{p}$.

18. Institute of Medicine (IOM). Dietary reference intakes for vitamin C, vitamin E, selenium and carotenoids. Washington, D.C.: National Academy Press, 2000a, $506 \mathrm{p}$.

19. Institute of Medicine (IOM). Dietary reference intakes for water, potassium, sodium, chloride, and sulfate. Washington, D.C.: National Academy Press, 2004a, $638 \mathrm{p}$.

20. Ismail FW, Khan RA, Kamani L, Wadalawala AA, Shah HA, Hamid SS, Jafri W. Nutritional status in patients with hepatitis C. J Coll Physicians Surg Pak. 2012;22(3):139-42.

21. Lameu EB, Gerude MF, Corrêa RC, Lima KA. Adductor policis muscle: a new anthropometric parameter. Rev Hosp Clín Fac Med. 2004;59(2):57-62.

22. Morgan MY, Madden AM, Soulsby CT, Morris RW. Derivation and validation of a new global method for assessing nutritional status in patients with cirrhosis. Hepatology. 2006;44(4):823-5.

23. Palowtsky JM. Treatment failure and resistance with direct-acting antiviral drugs against hepatitis C virus. Hepatology. 2011;53(5):1742-51.

24. Peng S, Plank LD, McCall,JL, Gillanders LK, McIlroy K, Gane E. Body composition, musclefunction, and energy expenditure in patients with liver cirrhosis: a comprehensive study. Am J Clin Nutr. 2007;85:1257-66.

25. Plauth M, Merli M, Kondrup J, Weimann A, Ferenci P, Müller MJ. Espen guidelines for nutrition in liver diseases and transplantation. Clinical Nutrition. 1997; 16:43-55.

26. Ritter L, Gazzola J. Nutritional evaluation of the cirrhotic patient: an objective, subjective or multicompartmental approach? Arq Gastroenterol. 2006;43(1):66-70.

27. Roongpisuthipong C, Sobhonlidsuk A, Nantiruj K, Songchitsomboon S. Nutri tional assessment in various stages of liver cirrhosis. Nutrition. 2001;17(9):761-5.

28. Schlüssel MM, Dos Anjos LA, Vasconcellos MTL, Kac G. Reference values of handgrip dynamometry of health adults: a population-based study. Clinical Nutrition 2008;27:601-7.

29. Schmidt MI, Duncan BB, Silva GA, Menezes AN, Monteiro CA, Barreto SM Chor D, Menezes PR. Chronic non-communicable diseases in Brazil: burden and current challenges. Lancet. 2011;9;61-74.

30. Shepard CW, Finelli L, Alter MJ. Global epidemiology of hepatitis C virus infection. Lancet Infect Dis. 2005;5:558-67.

31. Sociedade Brasileira de Hepatologia. Epidemiologia da infecção pelo vírus da hepatite C no Brasil. Available from: http://www.fmt.am.gov.br/trabalhos/anais/ virologia/infec_brasil.htm

32. World Health Organization, Geneva. Weekly Epidemiological Record. 1997;46:341-8. 